\title{
"Methods of ensuring flexibility of the budget process at holding enterprises of energy industry"
}

\begin{tabular}{|c|c|}
\hline AUTHORS & $\begin{array}{l}\text { Oleksii Mints (D https://orcid.org/0000-0002-8032-005X } \\
\text { R http://www.researcherid.com/rid/D-8302-2018 } \\
\text { Natalia Markina (D https://orcid.org/0000-0003-4933-2826 }\end{array}$ \\
\hline ARTICLE INFO & $\begin{array}{l}\text { Oleksii Mints and Natalia Markina (2019). Methods of ensuring flexibility of the } \\
\text { budget process at holding enterprises of energy industry. Economics of } \\
\text { Development, 18(4), 19-27. doi: 10.21511/ed.18(4).2019.03 }\end{array}$ \\
\hline DOI & http://dx.doi.org/10.21511/ed.18(4).2019.03 \\
\hline RELEASED ON & Monday, 24 February 2020 \\
\hline RECEIVED ON & Wednesday, 04 December 2019 \\
\hline ACCEPTED ON & Friday, 20 December 2019 \\
\hline LICENSE & $\begin{array}{l}(c) \text { EY } \\
\text { This work is licensed under a Creative Commons Attribution } 4.0 \text { International } \\
\text { License }\end{array}$ \\
\hline JOURNAL & "Economics of Development" \\
\hline ISSN PRINT & $1683-1942$ \\
\hline ISSN ONLINE & $2304-6155$ \\
\hline PUBLISHER & LLC "Consulting Publishing Company "Business Perspectives" \\
\hline FOUNDER & Simon Kuznets Kharkiv National University of Economics \\
\hline
\end{tabular}

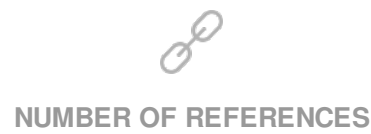

16

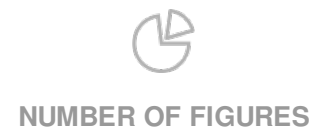

4

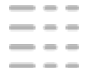

NUMBER OF TABLES

0

(C) The author(s) 2021. This publication is an open access article. 


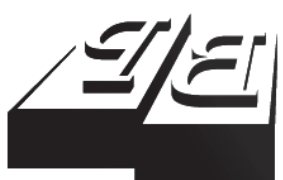

BUSINESS PERSPECTIVES

Publisher

LLC "CPC "Business Perspectives" Hryhorii Skovoroda lane, 10, Sumy, 40022, Ukraine www.businessperspectives.org

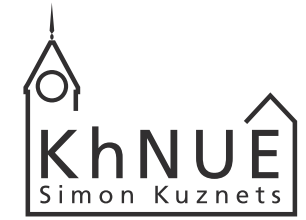

\section{S. KUZNETS KHNUE}

Founder

Simon Kuznets Kharkiv National University of Economics, Nauky avenue, 9-A, Kharkiv, 61166,

Ukraine

http://www.hneu.edu.ua/

Received on: 04th of

December, 2019

Accepted on: 20th of

December, 2019

(c) Oleksii Mints,

Natalia Markina, 2019

Oleksii Mints, Doctor of Science (Economics), Associate Professor, Head of the Department of Finance and Banking of the State Higher Education Institution «Pryazovskyi State Technical University», Ukraine

Natalia Markina, Postgraduate Student of the Department of Finance and Banking of the State Higher Education Institution «Pryazovskyi State Technical University», Ukraine

\section{(c) (i)}

This is an Open Access article, distributed under the terms of the Creative Commons Attribution 4.0 International license, which permits unrestricted re-use, distribution, and reproduction in any medium, provided the original work is properly cited.

\title{
METHODS OF ENSURING FLEXIBILITY OF THE BUDGET PROCESS AT HOLDING ENTERPRISES OF ENERGY INDUSTRY
}

\begin{abstract}
Achieving business success for a company is directly related to financial planning, budgeting and analysis of results. Any system is viable if it includes feedback elements that provide an analysis of what the system has done and current adjustments to the system's behavior as signals about its state. The article deals with the features of the budget process at energy enterprises as part of vertically oriented holding structures. The system formed by such enterprises is very complex, so it is necessary to take additional measures to maintain the efficiency of the budget process in such conditions. Therefore, an important issue is the organization of effective control in the budget execution system to make operational management decisions, which turns it into an effective tool for managing the enterprise.

The essence and importance of budget control of energy companies are revealed. The paper deals with the organization of budget planning at an enterprise of the energy industry. Models for budget development and budget execution processes were built and budget limits were adjusted for enterprises using the IDEF0 methodology. The methods of control over the budget execution of energy industry enterprises are considered. The essence and types of the process of adjusting the budget of enterprises are revealed.
\end{abstract}

\section{Keywords}

JEL Classification budget control, budget adjustment, limit, financial responsibility center, finance, enterprises

G30, M41, Q49

О. Ю. Мінц (Україна), Н. Ю. Маркіна (Україна)

\section{МЕТОДИ ЗАБЕЗПЕЧЕННЯ ГНУЧКОСТІ БЮДЖЕТНОГО ПРОЦЕСУ НА ХОЛДИНГОВИХ ПІДПРИЄМСТВАХ ЕНЕРГЕТИЧНОЇ ГАЛУЗІ}

\begin{abstract}
Анотація
Досягнення успіху в бізнесі для компанії безпосередньо пов’язано з питаннями фінансового планування, бюджетування та аналізу отриманих результатів. Наявність зворотного зв'язку необхідна для забезпечення життєздатності будь-якої економічної системи через постійне коригування її поведінки.

В статті розглянуто особливості бюджетного процесу на підприємствах енергетичної галузі у складі вертикально-орієнтованих холдингових структур. Система, яку утворюють такі підприємства є дуже складною, тому необхідно забезпечувати додаткові міри для збереження ефективності бюджетного процесу в таких умовах. Тому важливою $є$ проблема організації ефективного контролю в системі виконання бюджетів 3 метою прийняття оперативних управлінських рішень, що перетворює її в ефективний інструмент управління підприємством. Розкрито сутність, значення бюджетного контролю підприємств енергетичної галузі. В роботі розглянуто організацію бюджетного планування на підприємстві енергетичної галузі. Побудовано моделі процесів розробки та виконання бюджету, а також корегування бюджетних лімітів на підприємствах із використанням методології IDEF0. Розглянуто методи контролю виконання бюджету підприємств енергетичної галузі. Розкрито сутність та види процесу коригування бюджету підприємств.
\end{abstract}

\section{Ключові слова}

Класифікація JEL бюджетний контроль, корегування бюджету, ліміт, центр фінансової відповідальності, фінанси, підприємства G30, M41, Q49 


\section{ВСТУП}

В сучасних економічних умовах ефективна діяльність підприємств енергетичної галузі можлива тільки у складі вертикально-орієнтованих холдингових структур. Через складну організаційну та виробничу структуру, керуючі установи в складі холдингу гостро потребують оперативної економічної та фінансової інформації для оптимізації витрат, прийняття обгрунтованих управлінських рішень і досягнення запланованих фінансових результатів. Планування і контроль діяльності підприємств уявляються неможливими без формування бюджету як основного інструменту гнучкого управління. 3 його допомогою розробляється стратегія ефективного розвитку підприємства в умовах конкуренції, а також невизначеності в умовах ринкової економіки, і він служить важливим інструментом досягнення цілей холдингу. Але, навіть виважений і обгрунтований бюджет не буде ефективним інструментом управління підприємством без налагодженої системи зворотного зв'язку, тобто при відсутності ефективної системи контролю за його виконанням.

У науковій економічній літературі останніх років велика увага приділяється темі управління процесами бюджетування напідприємствах.Зокремаціпитання розглядалися такими зарубіжними, таківітчизняними вченими, як: Сігел, Шим [14], Данилочкіна [1], Білик [2], Лабинцев, Чухрова [8, 9], Бірт [3], Поддєрьогін [11], Самочкин [13], Терещенко [16], Федчишина [5] та ін. Але недостатньо розкритою залишається проблема організації зворотного зв’язку тобто контролю в системі бюджетування.

\section{1. МЕТА ДОСЛІДЖЕННЯ}

Метою дослідження є аналіз підходів до організації ефективного бюджетного процесу на підприємствах енергетичної галузі через забезпечення гнучкості та контрольованості бюджетного процесу.

Для досягнення поставленої мети було вирішено наступні завдання:

- виявлено основні етапи виконання бюджетного процесу, з урахуванням невизначеності зовнішніх факторів;

- проаналізовано склад компонентів організаційної структури вертикально-орієнтованих холдінгових підприємств енергетичної галузі та виявлено, які підрозділи приймають участь в процесі бюджетування та його основні інформаційні потоки;

- побудовано інформаційну модель процесу розробки та виконання бюджету, що відповідає організаційній структурі підприємств енергетичної галузі;

- побудовано інформаційну модель процесу корегування бюджетних показників.

Об’єктом дослідження є підприємства та вертикально-орієнтовані холдингові структури енергетичної галузі.

Предметом дослідження є процес бюджетування на підприємствах енергетичної галузі.

\section{2. РЕЗУЛЬТАТИ}

У процесі діяльності підприємств енергетичної галузі можуть виникати відхилення фактичних показників економічної діяльності підприємства від планових. Для своєчасного виявлення таких відхилень і прийняття відповідних управлінських рішень використовуються різноманітні методи бюджетного контролю.

Бюджетний контроль - це «вид управлінської діяльності, пов'язаний із перевіркою та оцінюванням результативності функціонування бюджетної системи на підприємстві відповідно до встановлених критеріїв і стандартів, та, зокрема, оцінювання бюджетів підприємства» [10]. 
Бюджетний контроль охоплює такі управлінські дії:

- перевірка виконання бюджетних показників та кінцевих результатів виконання бюджетів;

- ідентифікація факторів та причин виявлених відхилень;

- визначення недоліків у діяльності центрів відповідальності та загальних недоліків функціонування систем, що контролюються;

- визначення раціональності розподілу ресурсів підприємств та ефективності бюджетних витрат;

- виявлення неузгодженостей бюджетних показників;

- визначення ефективності бюджетного мотивування.

Загальну схему процесу контролю за виконанням бюджету можна представити наступним чином (Рисунок 1).

В процесі діяльності підприємства внаслідок впливу зовнішніх факторів, або недостатньо ефективного урахування внутрішніх факторів може виникнути відхилення від запланованих показників. Для виявлення цих відхилень складається звіт про виконання бюджету. В залежності від рівня відхилень можуть бути прийняти міри з корегування діяльності підприємства (у випадку незначних відхилень), чи корегування бюджету (якщо відхилення є значними).

Як випливає з аналізу Рисунку 1, основним інформаційним підгрунтям процесу здійснення бюджетного контролю є звіт про виконання бюджету. Цей документ містить порівняння запланованих і фактичних показників діяльності підприємства та розрахунок відхилень із зазначенням їх причин. Він складається із визначеним на підприємстві періодом відділом з планово-аналітичної роботи підприємства й адресований керівникам, які відповідають за прийняття управлінських рішень. Таким чином, звіт про виконання бюджету забезпечує зворотній зв’язок, що дає змогу здійснювати управління за відхиленнями [15].

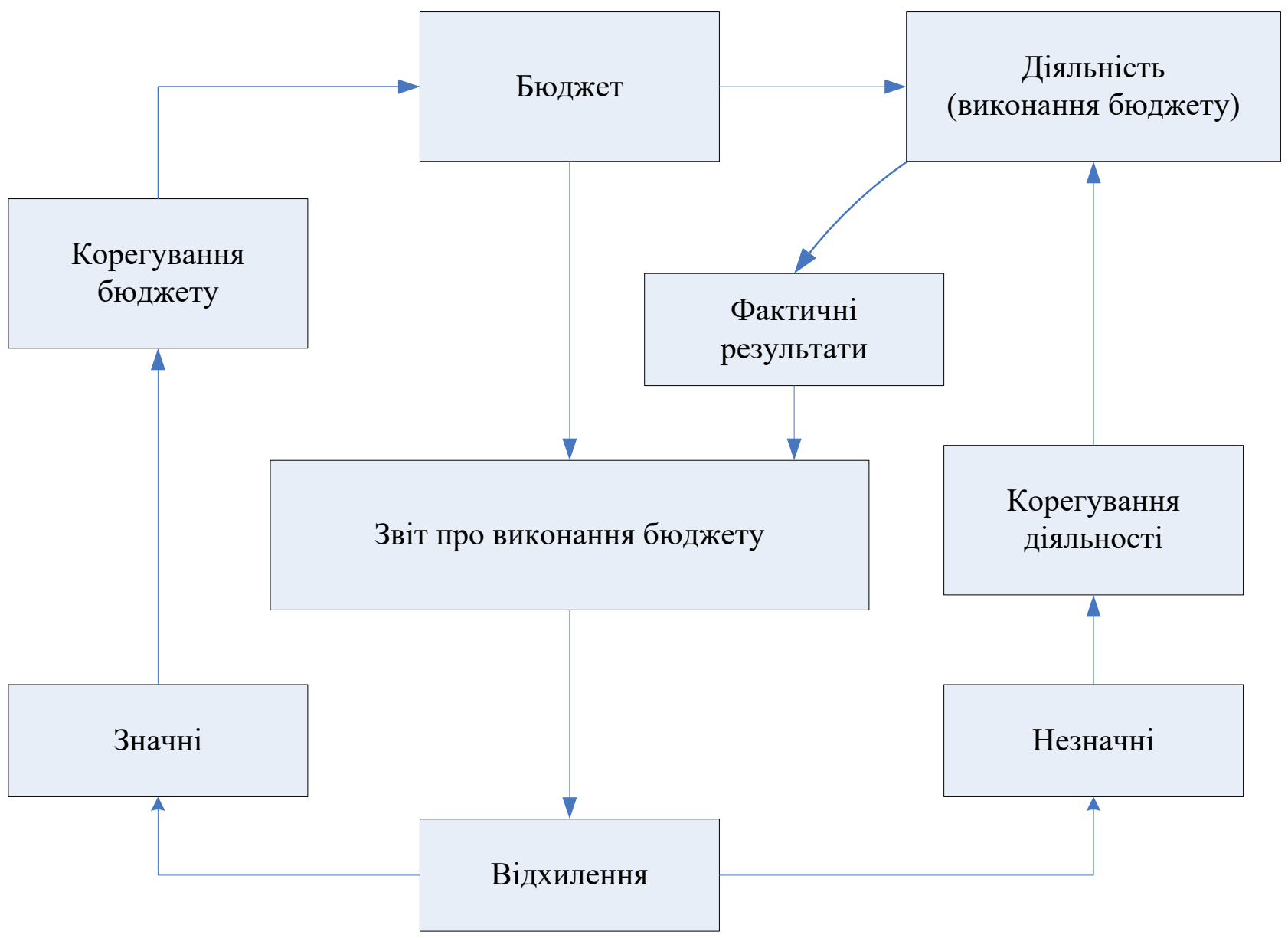

Джерело: Розроблено авторами за [12]

Рисунок 1. Схема процесу контролю за виконанням бюджету 
Відхилення в бюджеті можуть бути як позитивними, так і негативними. Від знаку відхилення залежить реакція підприємства в рамках бюджетного процесу [6].

В даний час найбільш поширеним підходом до формування фінансової структури холдингових підприємств є їі розгляд як сукупності центрів фінансової відповідальності (ЦФВ), кожен з яких розглядається, як окремий відносно самостійний елемент фінансової групи, має свій бюджет та володіє необхідними ресурсами і повноваженнями. В рамках холдингу можна виділити ЦФВ чотирьох рівнів:

1) холдинг в цілому;

2) самостійні підприємства, або філіали;

3) підрозділи підприємств, що входять до холдингу;

4) відділи у підрозділах підприємств.

До важливіших особливостей холдингу енергетичних підприємств відноситься однорідність його учасників. Тобто енергетичні підприємства та їх підрозділи не тільки споживають однакову сировину (енергоносії) та виробляють однакову продукцію (енергію), але часто навіть побудовані за одним проектом. Іншим важливим фактором $є$ великий вплив на економічну діяльність енергетичних підприємств з боку держави, через діяльність Національної комісії, що здійснює державне регулювання у сферах енергетики та комунальних послуг (НКРЕКП).

Таким чином, бюджетних процес на підприємствах енергетичної галузі має загальні та специфічні риси. Розглянемо загальні риси.

Поточний (оперативний) контроль за виконанням бюджету здійснюється шляхом узгодження заявок на платіж від ЦФВ. При цьому визначається відповідність заявки як до статей бюджету руху грошових коштів (БРГК), так і до статей бюджету доходів та витрат (БДВ).

На практиці можуть виникати ситуації, коли необхідно провести платежі, які не вписуються в бюджет. Наприклад, деякий ЦФВ за бюджетними статтями вже вичерпав ліміти, а за підписаним договором необхідно платити. Технічно, в цьому випадку можна провести платежі поза бюджетом, але таке рішення призведе до зменшення рівня контрольованості фінансових процесів в холдингу та ефективності самого бюджету як інструменту контролю. Тому вірним рішенням буде актуалізація бюджету (Рисунок 1).

Розглянемо детальніше організацію процесу бюджетного планування та супроводу виконання бюджету на підприємствах енергетичної галузі, з урахуванням специфічних рис, яку наведено на Рисунку 2 із використанням методології моделювання інформаційних потоків IDEF0 $[7,12,4]$. Для спрощення моделі, обсяг якої в межах статті є обмеженим, будемо розглядати відносини між ЦФВ рівнів 2 та 3 (за наведеною вище класифікацією), оскільки в даному випадку поєднується з одного боку відносна економічна самостійність у структурі холдингу ЦФВ рівня 2 (ЦФВ-2) та різноманітність виробничої та економічної діяльності ЦФВ рівня 3 (позначено як ЦФВ-3). Слід зазначити, що місце та роль у бюджетному процесі ЦФВ рівня 4 здебільшого збігається з ЦФВ-3.

Для підприємств енергетичної галузі характерно річне планування фінансової та виробничої діяльності 3 поквартальною розбивкою. Перед початком чергового року департаментом з фінансів ЦФВ-2 встановлюються загальні показники бюджетів (БДВ, БРГК) всієї компанії і окремих ЦФВ-3. За кожною бюджетною статтею ЦФВ-3 має річний ліміт і поквартальний план освоєння. В межах цих значень ЦФВ-3 повинні здійснювати свою діяльність, зокрема виконувати поточні і укладати нові договори.

Бюджетний процес розпочинається з аналізу планових показників виробництва та споживання енергії, а також з розрахунку всіх пов’язаних показників. На підставі отриманих результатів відбувається первісне визначення фінансових потреб, та встановлення лімітів на них.

Оскільки на початковому етапі бюджетування потреби та ліміти частіше за все не збігаються, далі 


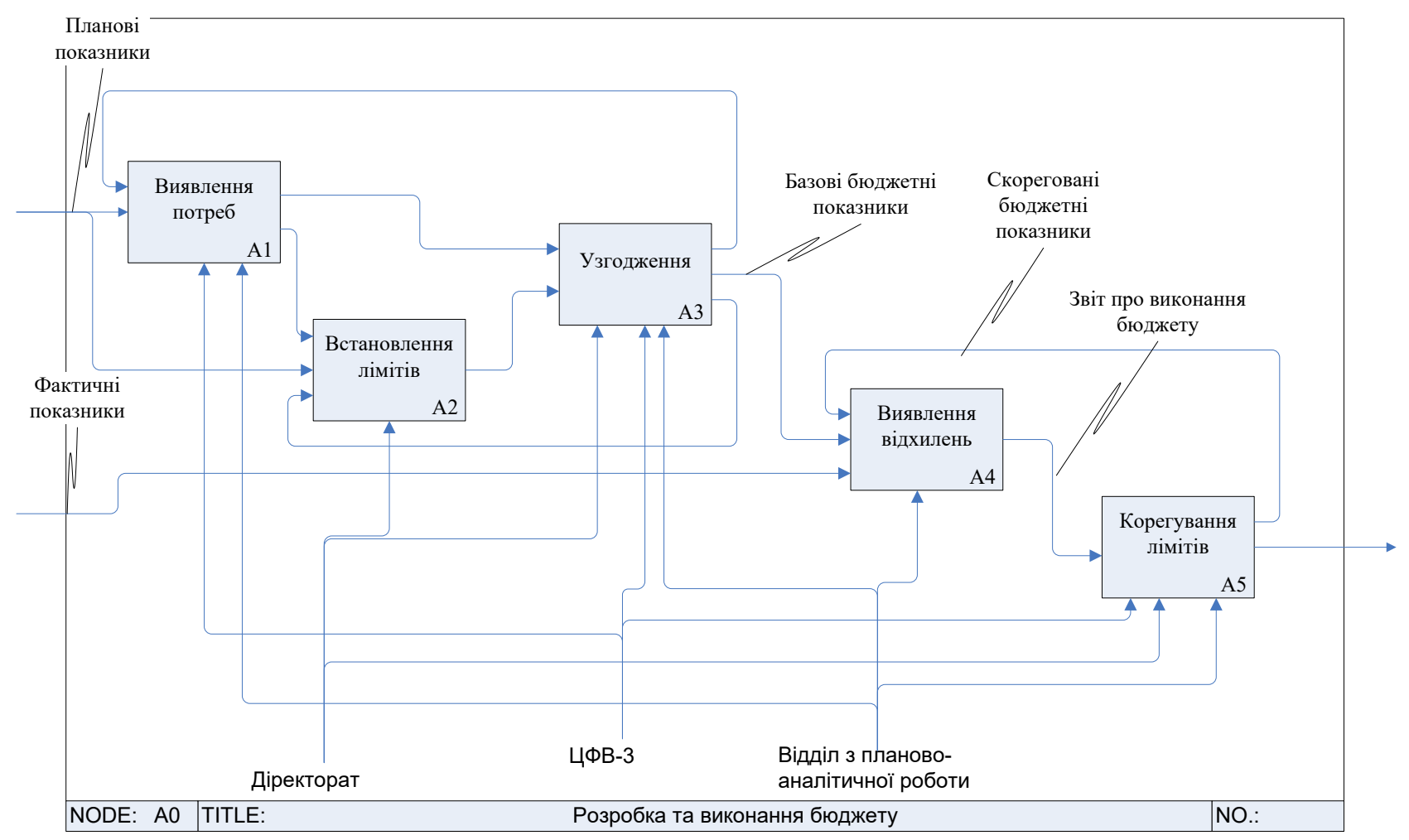

Джерело: Розроблено авторами.

Рисунок 2. Інформаційна модель процесу розробки та виконання бюджету

відбувається процес поступового їх узгодження (блок А3 в Рисунку 2). Результатом виконання блоків A1-А3 є річний бюджет підприємства, або холдингової структурної одиниці. Процедура узгодження бюджетів звичайно не враховує специфічні риси енергетичних підприємств, що визначає наявність резервів для вдосконалення процесу бюджетування, але це виходить за межи даного дослідження та може стати темою окремої роботи.

Як було зазначено вище, внаслідок природної індетермінованості економічних процесів, впродовж виконання бюджету виникає необхідність корегування бюджетних показників. Процесу корегування передує процедура виявлення відхилень (блок А4), результат якого на Рисунку 2 позначено, як «Звіт про виконання бюджету». Дану назву обрано для скорочення розміру моделі, та їі слід розуміти не тільки у вузькому сенсі (як щоквартальний звіт відділу з планово-аналітичної роботи), а як біль широкий спектр форм звітності та інформаційних повідомлень про відхилення від запланованих фінансових показників. Перевищення встановлених лімітів допустимо тільки після виконання процедури корегування бюджету. Корегування - це вимушена зміна лімітів бюджетних статей до початку уточнюючого планування на наступний квартал або в момент виникнення позапланового платежу.

На підставі інформації про відхилення може бути запущений блок А5, який містить механізм корегування бюджетних показників (у тому випадку, коли таке відхилення неможливо скорегувати поточними змінами діяльності підприємства (Рисунок 1).

Корегування лімітів може здійснюватися різноманітними способами, в залежності від суми відхилення та кількості ЦФВ, які будуть задіяні в процесі перерозподілу. Тому для розкриття механізму корегування необхідна декомпозиція блоку А5, яку наведено на Рисунку 3.

Процес корегування розпочинається з ідентифікації відхилень та визначення методу корегування, який буде застосовано в конкретному випадку. В моделі, яку наведено на Рисунку 3 , виділено кілька видів коригувань і пов’язаних з ними варіантів їх узгодження. Розглянемо їх детальніше. 


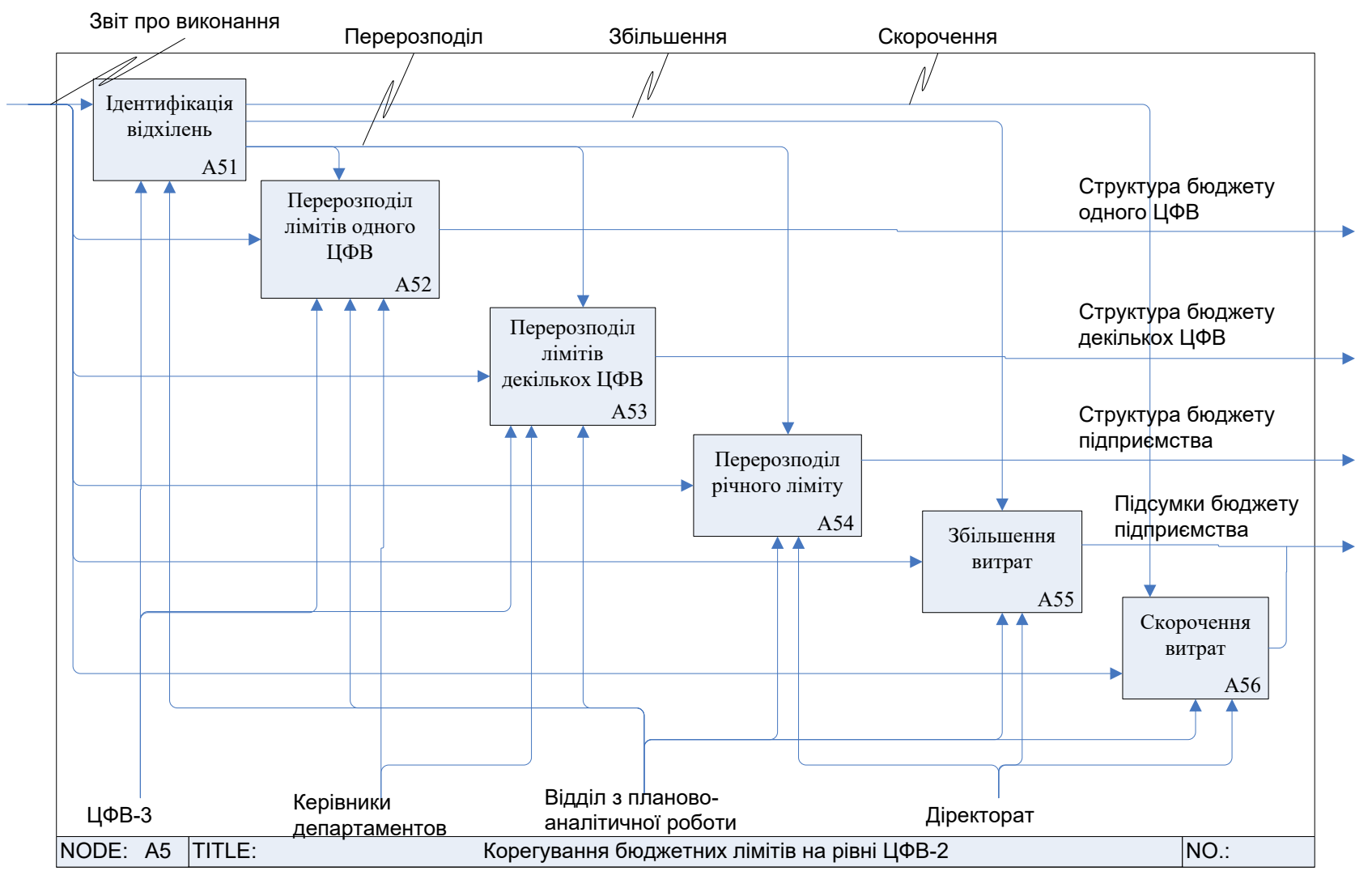

Джерело: Розроблено авторами.

Рисунок 3. Інформаційна модель процесу корегування лімітів бюджету підприємств енергетичної галузі

Перерозподіл лімітів одного ЦФВ-3 (блок А52). Ідентифікація необхідності такого корегування здійснюється на рівні ЦФВ, Зазвичай у веденні одного ЦФВ знаходиться кілька статей бюджету. Відповідальність за їх виконання знаходиться повністю на ЦФВ, як і рішення про збільшення лімітів однієї статті за рахунок скорочення лімітів інший. Подібні коригування узгоджуються тільки керівником ЦФВ-3 і направляються безпосередньо в відділ з планово-аналітичної роботи ЦФВ-2 для відображення змін в бюджеті.

Перерозподіл лімітів декількох ЦФВ (блок А53). Якщо кілька ЦФВ-3 є однорідними, що відповідає до специфіки підприємств енергетичної галузі, то вони можуть бути об'єднані за функціональною ознакою (виробництво, закупівлі і інше), і в залежності від поточної ситуації частина лімітів одних ЦФВ може бути спрямована на здійснення діяльності інших ЦФВ групи. Даний вид коригування не викликає зміну обсягів бюджету всього підприємства, але їх узгодження повинно відбуватися з відома всіх задіяних ЦФВ-3 і функціональних керівників. Такі перерозподіли також складають значну частину від операцій 3 корегування лімітів.

Перерозподіл річного ліміту (блок А54). Розглядаючи цей вид корегування слід наголосити, що кожна бюджетна стаття лімітується як квартальними значеннями, так і річними. Причому першорядну роль має річний ліміт, а квартальні значення лише уточнюють графік виконання. Саме тому перерозподіл лімітів ЦФВ має бути можливим не тільки в рамках квартальних значень, але і річних. Припустимо, ЦФВ необхідно оплатити послуги підрядника на підставі підписаного акта виконаних робіт. Ці витрати закладено в річний бюджет, але не освоєно вчасно, оскільки виконання робіт підрядником затягнулося на кілька тижнів. Згідно класичного підходу, неосвоєна сума повинна бути включена у витрати майбутнього кварталу в процесі уточнюючого планування. Якщо цей захід не виконано, ЦФВ може запропонувати коригування квартального ліміту за рахунок зменшення сум, що не були освоєні в минулих кварталах. 3 огляду на, що в даному випадку може виникнути розрив в БРГК, то такі коригування слід в обов’язковому порядку погоджувати з департаментом з фінансів. 
Наведені три види коригувань можуть поєднуватись більш складним чином. Наприклад, збільшення квартального ліміту однієї статті бюджету за рахунок скорочення річного ліміту іншої статті. Така ситуація часто відбувається, коли ЦФВ планувало освоєння значної суми протягом року, але через об’єктивні причини вона не може бути освоєна, зате може бути спрямована на інші потреби. У будь-якому випадку коригування бюджету, яке пов'язане з перерозподілом, дозволяє «залатати дірки» в бюджеті, не вдаючись до істотного його «перекроювання». Бюджетним регламентом (або іншими способами) необхідно донести до ЦФВ необхідність вишукувати можливість перерозподілу своїх лімітів перед тим, як їх збільшувати.

Проте, іноді не вдається провести коригування «всередині» бюджету, перерозподіливши суми між статтями, ЦФВ і періодами. У цьому випадку доводиться шукати додаткові кошти і переглядати ключові показники бюджету.

Збільшення витрат (блок А55). 3 одного боку, збільшення витратної статті - це найпростіший вид коригування. Він не вимагає від ЦФВ додаткової роботи з аналізу свого бюджету - треба просто попросити ще грошей, обгрунтувавши, на що вони потрібні. Але з іншого боку, кожен ЦФВ знає, як складно обгрунтувати перед вищим керівництвом необхідність тих чи інших непередбачених витрат. Дійсно, якщо ЦФВ потребує збільшення витрат, то підприємству необхідно шукати джерела їх фінансування. Такий підхід мотивує ЦФВ не тільки до пошуку резервів свого бюджету, а й до більш якісного його планування.

Скорочення витрат (блок А56). Про цей вид коригування бюджету витратні ЦФВ часто «забувають». Тому для вдосконалення бюджетного процесу слід запровадити заходи з мотивації ЦФВ-3 до своєчасного зниження планових витрати для досягнення прийнятних показників освоєння або вибудовувати свою діяльність так, щоб освоєння бюджету йшло згідно затвердженого плану. В обох випадках діяльність ЦФВ стане більш ефективною для підприємства.

Аналіз моделі інформаційних потоків, що наведена на Рисунку 3 показує надмірність ресурсів, що задіяні в блоках A52 та А53, виконання яких потребує участі ЦФВ-3, керівників відповідних департаментів та відділу з планово-аналітичної роботи. В той же час, аналіз діяльності існуючих підприємств енергетичної галузі показав, що кількість запитів на перерозподіл лімітів в рамках одного ЦФВ становить більш ніж половина від їх загальної кількості, а разом із операціями щодо перерозподілу лімітів декількох ЦФВ їх кількість доходить до 70\%. Крім того переважна більшість таких операцій з корегування стосується порівняльно невеликих сум. Оскільки ї виконання не викликає змін обсягів ані квартального, ані річного бюджетів, для забезпечення гнучкості процесу бюджетування, процес їх затвердження має бути організованим максимально просто і з найменшим числом узгоджувальних осіб.

В даний час ЦФВ-3 не має в своєму розпорядженні повноважень щодо корегування відхилень від бюджету. Будь-які корегування бюджетних показників, навіть у випадку простого перерозподілу сум (що за Рисунком 1 відноситься до корегування діяльності), потребують узгодження з ЦФВ-2, що знижує загальну ефективність менеджменту підприємства та процесу бюджетування.

Таким чином, можна запропонувати заходи щодо децентралізації процесів корегування бюджетів та надання до ЦФВ-3 повноважень щодо перерозподілу лімітів в межах одного, чи декількох однорідних ЦФВ (Рисунок 4).

Через перерозподіл повноважень, як показано на Рисунку 4, можна істотно зменшити транзакційні витрати бюджетного процесу, підвисити його гнучкість та оперативність. Зрозуміло, що надання повноважень ЦФВ-3 щодо перерозподілу бюджетних показників має здійснюватися в межах відповідних лімітів, для запобігання можливих негативних наслідків від непрофесійних дій. 

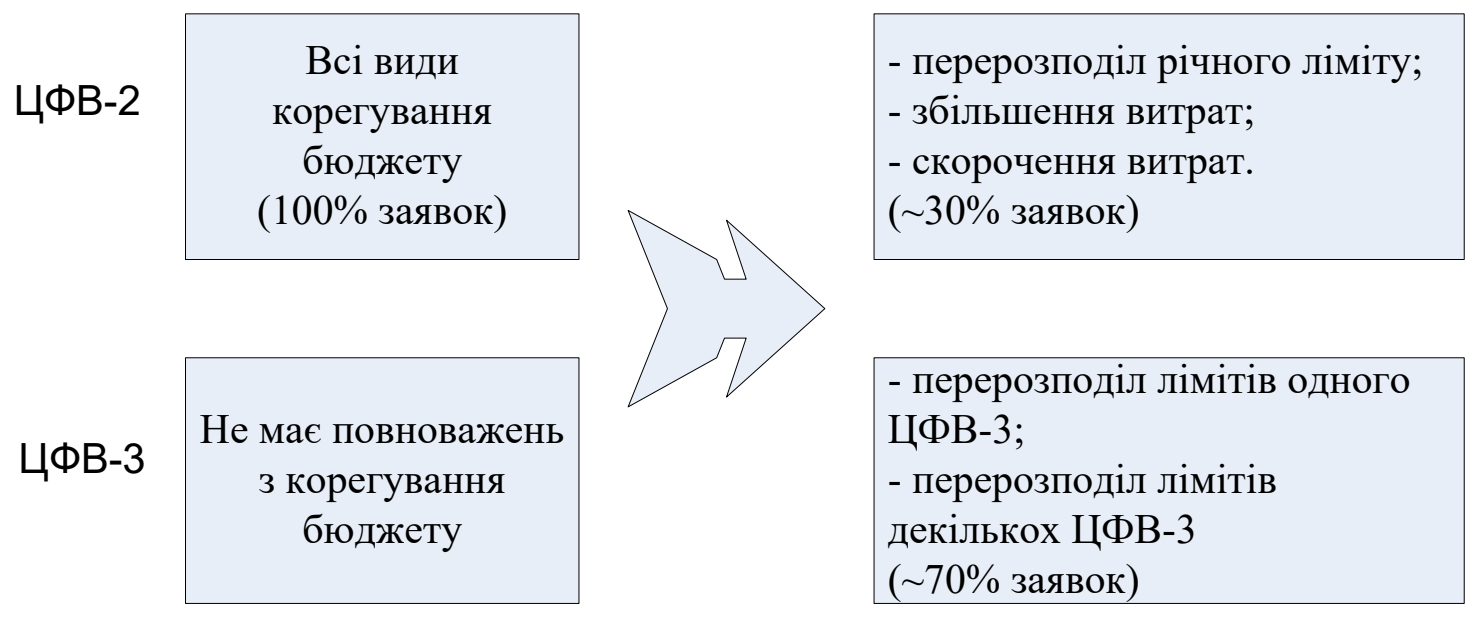

Джерело: Розроблено авторами.

\section{Рисунок 4. Зміни щодо розподілу повноважень з процесу корегування лімітів бюджету підприємств енергетичної галузі}

Таким чином, ефективне бюджетування неможливо без залучення ЦФВ всіх рівнів. Причому не варто обмежувати участь ЦФВ-3 тільки етапом планування бюджету. Децентралізація та актуалізація бюджетного процесу дозволить бачити актуальну картину діяльності підприємства, сприятиме підвищенню загальної культури фінансового планування, а весь процес бюджетування роблять реальним інструментом управління компанією. Серед напрямків подальшого дослідження процесів бюджетування на підприємствах енергетичної галузі слід відмітити вдосконалення та оптимізацію процесу узгодження бюджетів з урахуванням однорідності підприємств холдінгу, що дозволить запровадити крос-перевірку бюджетів та зменшити загальні витрати групи підприємств.

\section{СПИСОК ЛІТЕРАТУРИ}

1. Anankina, E., Danilochkin, S., \& Danilochkina, N. (1998). Kontrolling kak instrument upravleniya predpriyatiyem [Controlling as an enterprise management tool] (65 p.). Moskva: Audit YuNITI. (In Russian)

2. Bilyk, M. (2003). Biudzhetuvannia u systemi finansovoho planuvannia [Budgeting in the financial planning system]. Finance of Ukraine, 3, 97-109. (In Ukraine)

3. Birt, J., Chalmers, K., Maloney, S., Brooks, A., \& Oliver, J. (2017). Accounting: Business reporting for decision making (592 p.). John Wiley \& Sons.

4. Cheremnyh, S., Semenov, I., \& Ruchkin, V. (2003). Strukturnyy analiz sistem: IDEF-tekhnologii [Structural Analysis of Systems: IDEF Technologies] (207 p.). Moscow: Finansy i statistika. (In Russian)

5. Fedchishina, N. (2016). Oblik i biudzhetuvannia v upravlinni diialnistiu pidpryiemstva [Accounting and budgeting in the management of the enterprise] (Candidate's thesis) (237 p.). Kyiv: NASOU. (In Ukraine). Retrieved from http://nasoa.edu.ua/wp-content/uploads/zah/ fedchyshyna_dis.pdf

6. Gerasimova, L. (2011). Upravlencheskij uchet: teoriya i praktika [Management Accounting: Theory and Practice] (508 p.). Rostov-na-Donu: Feniks. (In Russian)

7. Kovalev, S., \& Kovalev, V. (2012). Sovremennyye metodologii opisaniya biznes-protsessov - prosto o slozhnom [Modern methodologies for describing business processes - simply about difficult]. (In Russian). Retrieved from http://www.betec.ru/indexprint.php?id=6\&sid=27

8. Labyntsev, N. (2015). Organizatsiya byudzhetnoy modeli v tekhnologii upravlencheskogo ucheta [Organization of a budget model in management accounting technology]. Problemy ucheta, analiza, audita i statistiki v usloviyah rynka - Problems of accounting, analysis, audit and statistics in market conditions, 18, 43-49. (In Russian)

9. Labyntsev, N., \& Chukhrova, O. (2013). Upravlencheskiy uchet i byudzhetirovaniye kak obyazatelnoye usloviye povysheniya effektivnosti deyatel'nosti kommercheskiy organizatsiy [Management accounting and budgeting as a prerequisite for increasing the efficiency of commercial organizations]. Uchet i Statistika - Accounting and Statistics, 3, 112-121. (In Russian)

10. Pankov, V., Yeleckih, S., \& Mihajlichenko, N. (2007). Kontroling i byudzhetuvannya finansovo-gospodarskoyi diyalnosti pidpriyemstva [Controlling and budgeting of financial and economic activity of the enterprise] (112 p.). Kyiv: Tsentr uchbovoi literatury. (In Ukraine)

11. Poddierohin, A., \& Naumova, L. (2011). Finansova stiikist pidpryiemstv u ekonomitsi Ukrainy [Financial stability of enterprises in the economy of Ukraine] (184 p.). Kyiv: KNEU. (In Ukraine)

12. Repin, V. (2007). Biznes-processy kompanii: postroenie, analiz, reglamentaciya [Business processes of the company: construction, analysis, regulation] (240 p.). Moscow: RIA «Standarty i kachestvo». (In Russian) 
13. Samochkin, V. (2003). Gibkoe razvitie predpriyatiya. Analiz i planirovanie [Flexible development of the enterprise. Analysis and Planning] (336 p.). Moscow: Delo. (In Russian)

14. Shim, D., \& Sigel, D. (2009). Osnovy kommercheskogo byudzhetirovaniya [Fundamentals of Commercial Budgeting] (474 p). SPb: BiznesMikro. (In Russian)

15. Sysoev, N., \& Molozhavenko, I. (2015). Organizaciya provedeniya proverochnyh procedur kak instrument sistemy vnutrennego kontrolya [Organization of verification procedures as an instrument of the internal control system]. Upravlencheskyi uchet - Management Accounting, 4(284). 37-42. (In Russian)

16. Tereshenko, O. (2004). Teoretichni zasadi byudzhetuvannya na pidpriyemstvi [Theoretical principles of budgeting at the enterprise]. Finance of Ukraine, 11, 17-23. (In Ukraine) 